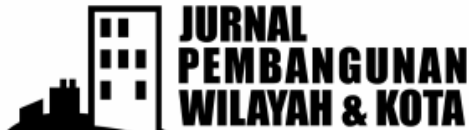

\section{Pengembalian Fungsi Daerah Sekitar Sungai: Konflik dan Tantangan Dalam Proses Regenerasi Sungai Cikapundung, Bandung}

\author{
Sevina Mahardini ${ }^{1}$ \\ Diterima : 7 Mei 2012 \\ Disetujui : 8 Juni 2012
}

\begin{abstract}
The study examines the conflicts and challenges in a public space refunctioning project frequently found among the government and the civil society, taking a case study in Cikapundung river. The theme of the study is "jeux d'acteurs" in French or stakeholder strategy in English. The study employs qualitative method by interviewing stakeholders and experts, supported by secondary data from the Government, stakeholder notes, workshops, and personal blogs. Stakeholder analysis has identified the interests of each actor involved in the Cikapundung river bank project. Economic interest came from the government and investors, social interest came from non-governmental organizations and local communities, while environmental issues have been the concern of non-governmental organizations and creative organizations. Emerging conflicts between the civil society and the government has been a sign of failure to establish good project governance (gouvernance du projet in French). Stakeholders could not present their concerns in more positive ways, as sources of ideas to improve the river. It was concluded that as a result of lack in integration of interests, a proper model of public space in the Indonesian context is difficult to find.
\end{abstract}

Key words: public space, the regeneration process of riverbank, civil society and government conflict

\begin{abstract}
ABSTRAK
Studi ini mempelajari konflik dan tantangan yang muncul dalam proyek pengembalian fungsi ruang publik dimana peran pemerintah dan civil society seringkali mengalami benturan, dengan mengambil studi kasus Sungai Ckapundung. Tema studi ini adalah "jeux d'acteurs" dalam bahasa perancis, atau strategis' stakeholders dalam bahasa inggris. Studi ini menggunakan metode kualitatif dengan wawancara stakeholder dan ahli terkait dan penggunaan data sekunder dari instansi pemerintah, catatan stakeholder dalam workshop ataupun blog pribadi. Melalui analisis stakeholder, studi ini menemukan kepentingan dari masing-masing aktor yang terlibat dalam proyek di daerah sekitar sungai Cikapundung. Kepentingan ekonomi datang dari pemerintah dan investor, kepentingan sosial muncul dari organisasi non pemerintah dan masyarakat setempat, dan isu lingkungan yang menjadi perhatian organisasi non pemerintah dan organisasi kreatif di Bandung. Kemunculan konflik antara masyarakat sipil dan pemerintah merupakan pertanda bahwa pemerintah telah gagal dalam membentuk "gouvernance du projet" atau sistem pemerintahan untuk sebuah proyek. Stakeholder-stakeholder tersebut tidak dapat membawa perhatian mereka dengan cara yang positif, yakni sebagai sumber ide untuk mengembangkan sungai tersebut. Dapat disimpulkan bahwa akibat kurangnya integrasi kepentingan, sebuah model mengenai ruang publik sesuai dengan konteks di Indonesia, menjadi tidak mudah untuk ditemukan.
\end{abstract}

Kata kunci: ruang publik, regenerasi sungai, konflik masyarakat sipil dan pemerintah

\footnotetext{
${ }^{1}$ Pemerintah Daerah Kota Pekalongan, Jawa Tengah

Kontak Penulis : sevinamahardini@gmail.com
} 


\section{PENDAHULUAN}

Pengembalian fungsi ruang publik merupakan tema aktual bagi masyarakat dunia saat ini. Perbaikan kualitas ruang kota, pada ruang yang biasa disebut sebagai ruang rusak atau ruang yang terlupakan, sering menjadi ide utama pada proyek-proyek penataan kota ${ }^{2}$. Monica Miranda dalam penelitiannya mengenai festival urban di Eropa dan Amerika, melihat kecenderungan perbaikan ruang publik pada ruang-ruang yang terlupakan dengan menciptakan pusat-pusat keramaian seperti restaurant atau pasar di ruang terbuka, atau penataan bantaran sungai sebagai pusat aktivitas warga masyarakat. Beberapa penelitian di Perancis, juga mengungkapkan adanya pengembangan ruang-ruang publik pada daerah yang tidak bisa digunakan, seperti halnya daerah bekas rel kereta api atau kawasan industri yang tidak berjalan lagi. Fenomena ini muncul sebagai dampak kuatnya kesadaran masyarakat mengenai kualitas ruang kotanya. Untuk itulah, dengan mengambil kasus penanganan Sungai Cikapundung di Bandung, Indonesia, studi ini bermaksud mengangkat sebuah tema ruang publik yang menjadi objek kontroversi dan sumber debat stakeholder terkait.

Bandung, kota terpadat kedua di Indonesia, merupakan kota yang sedang mengalami metropolitanisasi. Dengan jumlah penduduk sekitar 2,5 juta jiwa pada kota inti dan sekitar 7 juta pada aglomerasinya, permasalahan ruang dan lingkungan sering bermunculan dan menjadi topik pembicaraan stakeholder terkait, baik dari pemerintah ataupun swasta. Tema ini merupakan suatu tantangan bersama bagi stakeholder, dimana setiap aktor akan berusaha menunjukkan kemampuannya untuk mengembangkan ruang kotanya.

\section{METODE PENELITIAN}

Data yang digunakan berasal dari survei lapangan, data instansi pemerintah, dan juga berbagai informasi yang berasal dari sumber yang lebih personal. Terkait dengan kronologi permasalahan dan problem aktual tentang proyek terkait, informasi umum yang berasal dari berbagai blog organisasi non pemerintah dan komunitas masyarakat setempat, dan juga koran nasional juga digunakan sebagai data pelengkap.

a. Survei lapangan, yang dilakukan pada tanggal 5-23 Juli 2011. Dengan menggunakan biaya dari pemerintah Perancis, pada awalnya, melakukan survei lapangan di Indonesia dilakukan dengan fokus isu metropolitanisasi di Indonesia. Namun demikian, isu tersebut kemudian mengerucut pada pertanyaan hipotesis mengenai pengembalian fungsi ruang di daerah sekitar sungai di Bandung. Di Bandung, wawancara dilakukan dengan 11 stakeholder terkait, baik publik dan swasta dan juga berasal dari tingkat kota maupun nasional.

b. Untuk berbagai informasi pendukung mengenai situasi proyek aktual, digunakan data-data elektronik dari pemerintah dan juga hasil-hasil workshop yang diselenggarakan organisasi non pemerintah, serta foto-foto kegiatan workshop tersebut. Kemudian untuk melengkapinya, wawancara dilakukan melalui sambungan telepon dengan perwakilan pemerintah setempat dari Paris, Perancis.

\footnotetext{
${ }^{2}$ MIRANDA, Mónica (2010) L'evenement urbain festif : vers une " gestion de site exploratoire » sur l'espace public ?, École Doctorale "Ville, Transports Et Territoires, L'université Paris Est,», 492 p, Dir. Alain Bourdin.
} 


\section{RUANG LINGKUP WILAYAH STUDI}

Permasalahan ruang dan lingkungan pada studi ini akan berfokus pada daerah sekitar sungai di Bandung. Pada kenyataannya, permasalahan ruang pada daerah sekitar sungai terjadi di berbagai sungai yang melintas di Kota Bandung, namun untuk studi ini, ruang lingkup akan dibatasi pada Sungai Cikapundung (Lihat Gambar 1: Lokasi Studi Kasus). Pada awal riset, terkait dengan kawasan di sekitar sungai, dua permasalahan yang menarik untuk diangkat, yakni regenerasi sungai sebagai ruang publik pada Sungai Cikapundung yang terletak di bagian barat Kota Bandung, dan juga mengenai penanganan banjir di daerah sekitar Sungai Cikapundung bagian timur Kota Bandung. Namun demikian, untuk membatasi ruang lingkup materi, pada akhirnya lebih untuk mengangkat bagian Sungai Cikapundung bagian barat (lihat Gambar 2: situasi Sungai Cikapundung) sebagai tema studi. Pertimbangan pemilihan studi kasus ini terkait dengan konteks lokasinya di pusat kota, yang kemudian memunculkan berbagai permasalahan kota; lingkungan, sosial, ekonomi, dan juga politik.
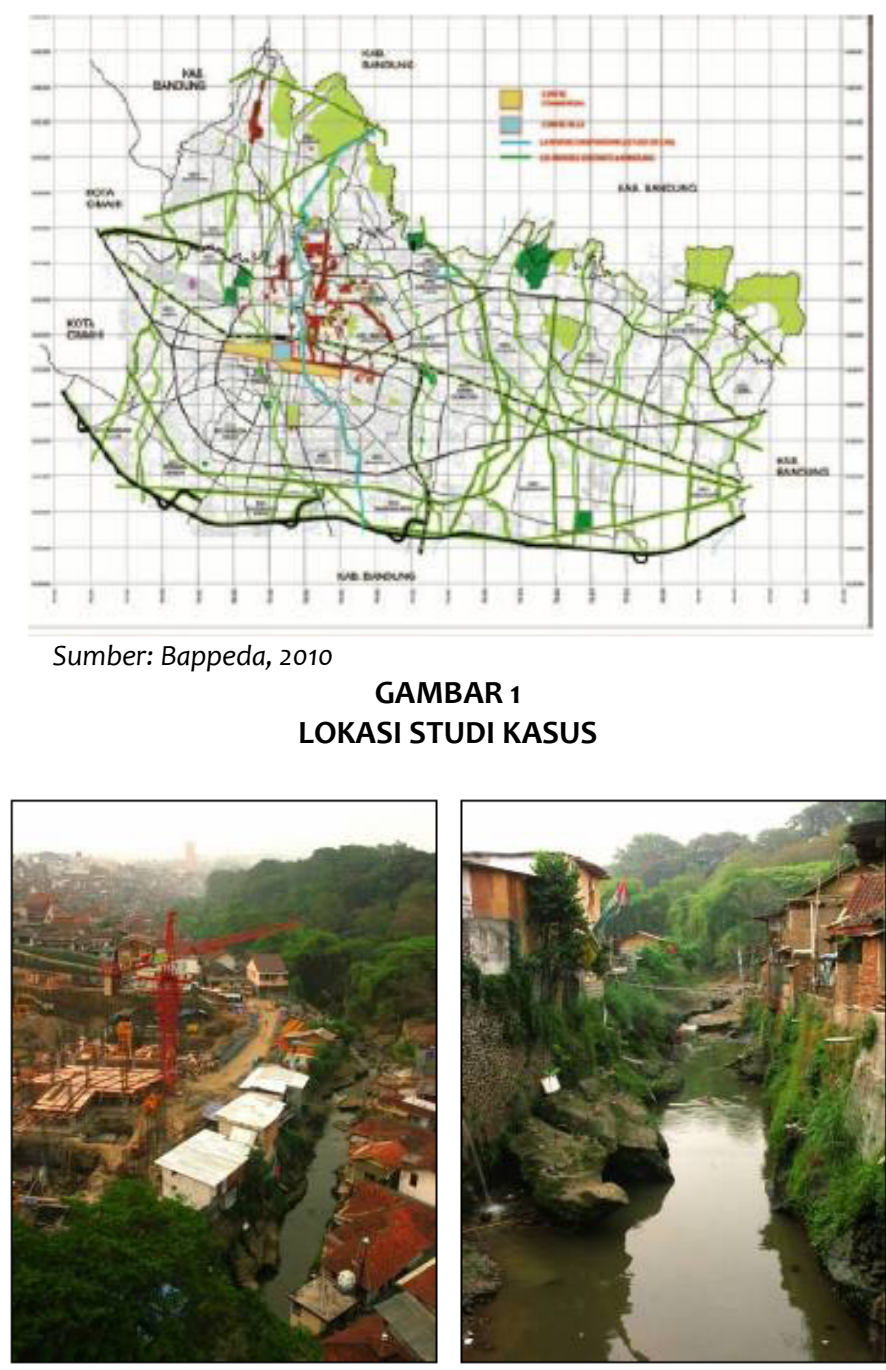

Sumber: BUCHOUD, 2011

GAMBAR 2

SITUASI SUNGAI CIKAPUNDUNG 


\section{PENGARUH URBANISASI DAN METROPOLITANISASI PADA PERKEMBANGAN DAERAH SEKITAR SUNGAI CIKAPUNDUNG BANDUNG}

Selain kegiatan pembangunan yang semakin lama semakin berjauhan dan juga menghabiskan lahan, terdapat pula proses perubahan ruang yang bukan dilakukan oleh pengembang ataupun pemerintah setempat, namun lebih atas inisitatif penduduk itu sendiri. Hal ini juga turut mengubah wajah kota. Urban sprawl yang berkaitan dengan pembentukan kota, secara informal ini berkembang sejauh $10 \mathrm{~km}$ dari Bandung, sebagai kota intinya.

Berkaitan dengan situasi di pusat kota, Ridwan Kamil, salah satu urban planner mengemukakan fenomena perumahan informal di Indonesia, yang disebut Kampung Kota.

Disekitar tahun 1960, terdapat pertumbuhan penduduk yang sangat pesat, dan sejak saat itu Lembah Cikapundung menjadi daerah pemukiman liar, tidak ada lagi permukiman formal, morfologi daerah tersebut berkarakter organik, sebagaimana kita biasa sebut sebagai kampung kota, (KAMIL, 2011).

Fakta lain diungkap melalui riset mahasiswa ITB tentang sejarah kawasan permukiman di sekitar Sungai Cikapundung12. Menurut mereka, urbanisasi terjadi karena beberapa faktor dan dalam jangka waktu yang lama. Awalnya, penduduk desa di sekitar Kota Bandung meninggalkan desanya ke Kota Bandung dengan alasan ekonomi dan untuk mengatasi kemiskinannya. Mengingat kontrol dari pemerintah setempat yang lemah, tidak ada aturan yang tegas yang membatasi proses bermukimnya warga di pinggiran sungai Cikapundung (Pratomo dkk, 2010). Eksodus penduduk dari desa ini menandai titik dimulainya proses pemadatan penduduk di pusat kota, yang umumnya dihuni oleh masyarakat berpenghasilan rendah, dimana secara kultur dan sosial kurang beradaptasi untuk hidup pada daerah permukiman perkotaan yang padat. Proses ini kemudian berlanjut melalui urbanisasi yang kedua, dimana faktor utamanya adalah berkembangnya Bandung sebagai kota pelajar. Kenyataan bahwa kota ini berkembang sebagai kota pelajar, menyebabkan munculnya kebutuhan sewa tempat tinggal atau yang biasa disebut tempat kost. Kebutuhan akan harga yang murah dan kedekatan lokasi dengan pusat universitas, semakin menambah tingkat urbanisasi di sekitar daerah Cikapundung.

Kampung kota merupakan kawasan hunian informal dimana keberadaan infrastrukturnya tidak direncanakan dari awal, namun penyediaannya lebih pada faktor kebutuhan. Akibatnya, morfologi kawasan ini memiliki bentuk organik dan dengan kenyataan tidak adanya keteraturan dan infrastrukur yang cukup, maka banyak pihak mengkonotasikan kampung dengan permukiman kumuh, walaupun hal ini tidak mutlak kebenarannya. Ridwan KAMIL arsitek-penata kota, mengindikasikan bahwa di pusat Kota Bandung, sebagian besar penduduk tinggal di tanah-tanah kosong di daerah sekitar Sungai Cikapundung. Berdasarkan studi Dinas Cipta Karya Kota Bandung, di Kota ini terdapat lebih dari 50 hektar kawasan hunian yang kumuh dari 49 kawasan di Bandung.

Gambar dan peta di bawah ini menunjukan kondisi permukiman di sekitar Sungai Cikapundung sangat membahayakan (Dokumen SPPIP RKPPP). Luasan permukiman informal ini melingkupi separuh dari kawasan. Situasi dan degradasi lingkungan di daerah sekitar Sungai Cikapundung dan ditambah dengan tekanan harga tanah yang semakin mahal, memunculkan pertanyaan mengenai pentingnya regenerasi sungai sebagai ruang publik kota. 


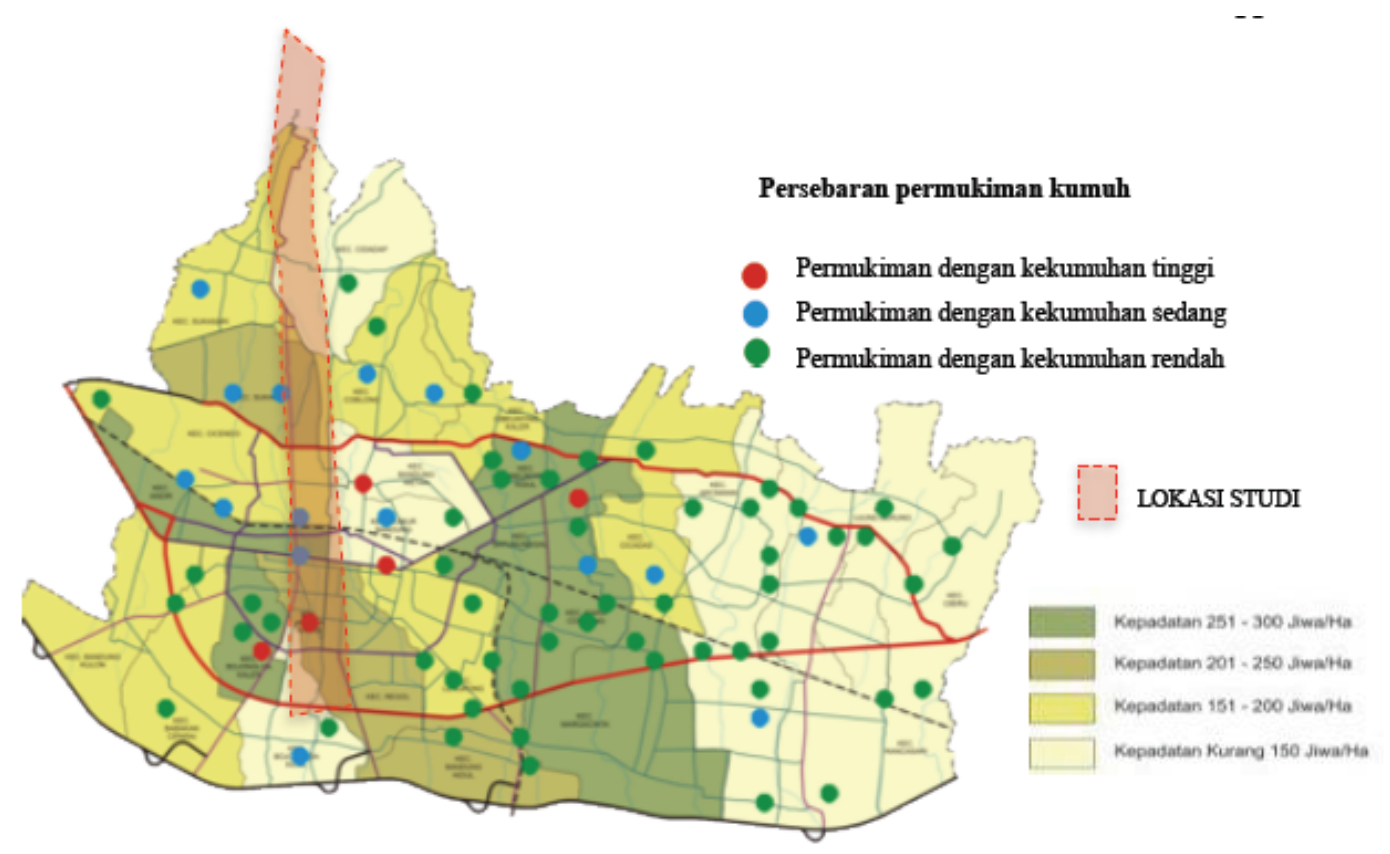

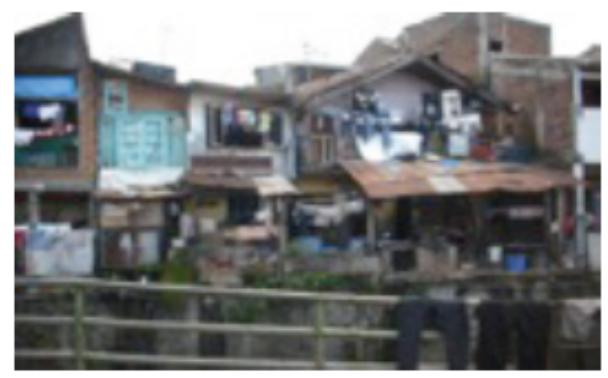

Kepadatan bangunan dan minimnya sarana sanitasi menyebabkan degradasi kualitas bangunan

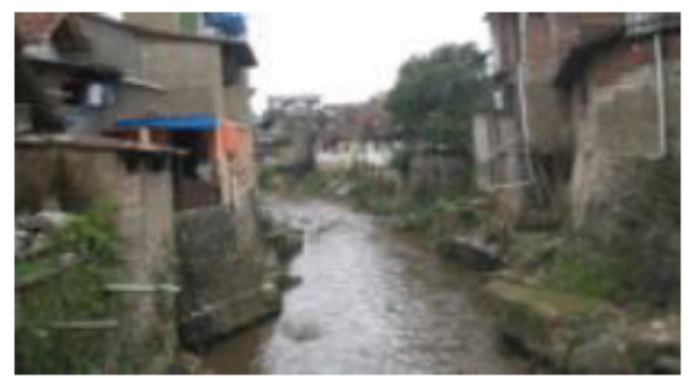

Permukiman kumuh di pinggir sungai Cikapundung.

Tidak adanya instalasi sanitasi yang layak di setiap rumah, menyebabkan penduduk membuang air kotor langsung ke sungai.

Sumber : Dinas Tata Ruang Cipta Karya Kota Bandung, 2010

\section{GAMBAR 3 \\ PETA DAN SITUASI PERMUKIMAN KUMUH DI SEKITAR SUNGAI CIKAPUNDUNG}

\section{MODEL BARU PENGEMBALIAN FUNGSI RUANG PUBLIK MASYARAKAT SIPIL DI INDONESIA}

Sejak krisis moneter di Indonésia tahun 1997 dan reformasi politik pada tahun 1998, situasi politik dan ekonomi negara ini berubah secara radikal. Secara ekonomi, sebagaimana disebutkan Charles Goldblum, urbanist yang tertarik masalah urbanisasi di Asia Tenggara, situasi pada tahun 1997 diwarnai dengan arus aliran modal pada industri dan finance menuju ke sistem yang lebih liberal dari masa sebelumnya. Selain itu, secara bersamaan situasi politik juga berevolusi dengan berdirinya berbagai partai politik, kurang lebih 50 partai politik. Mulai saat itu, masyarakat Indonesia menjadi lebih sensitif terhadap politik lokal, terutama dalam kaitannya pelaksanaan demokrasi partisipatif. Sejak tahun 1998, sebuah proses tranformasi 
secara insitusional mempengaruhi perubahan kondisi politik, sosial, ekonomi dan juga budaya yang berkembang sedikit demi sedikit dalam masyarakat Indonesia.

Situasi ini terjadi juga di Bandung, yang merupakan kota budaya, dimana dinamika ini muncul dalam bidang sosial budaya, politik, dan ekonomi. Berangkat dari permasalahan regenerasi Sungai Cikapundung sebagai ruang publik, akan dianalisis pendekatan baru yang diangkat oleh masyarakat sipil di Bandung dalam menghadapi kebijakan Pemerintah, yang dianggap kurang sesuai dengan realita yang ada. Pada bab ini akan dibahas terlebih dahulu peranan penduduk sebagai kekuatan penting dalam masyarakat sekarang ini, dan kemudian dilanjutkan dengan pembahasan tentang keberadaan forum masyarakat yang mampu memobilisasi elemen masyarakat dan mengintervensi kebijakan pemerintah.

\section{Gerakan Menuju “ Engagement Public” Terhadap Ruang Publik}

Gerakan terbaru forum ini adalah mengajak warga masyarakat untuk berpartisipasi pada kegiatan «Bandung Berkebun, Bandung urban farming» atau dalam bahasa perancis «'agriculture urbaine dans les espaces oubliés». Ide gerakan ini berasal dari Ridwan Kamil yang muncul sekitar bulan februari 2011. Pada saat ini, anggota aktif komunitas ini sebanyak 20 orang dan anggota pasifnya lebih dari 100 orang. Tujuan dari gerakan ini adalah mengubah ruang-ruang kosong menjadi lahan pertanian yang produktif dengan menanaminya dengan sayuran agar penduduk lebih dapat memanfaatkan dalam kehidupan sehari-hari (Blog komunitas Bandung Berkebun, http://m.paseban.com/?mod=content\&act=read\&id=1728, 2011). Walaupun pada awalnya, gerakan ini tidak ditujukan bagi kawasan Cikapundung, namun kemudian Wakil Walikota memberikan kebijakan bahwa kegiatan ini dapat dilakukan di kawasan sepanjang Sungai Cikapundung.

Kita mendukung ini Bandung Berkebun untuk bisa dilaksanakan di kawasan sekitar Sungai Cikapundung. Kita akan melakukan distribusi bibit bagi para penduduk yang tinggal disekitar kawasan tersebut. Kegiatan ini untuk melengkapi program Cikapundung Bersih. Dengan memanfaatkan lumpur sedimentasi sungai, kita berharap bahwa kawasan Cikapundung tidak hanya bersih dari lumpur sedimentasi tetapi juga akan lebih terlindungi secara lingkungan.

«Bandung initiative» juga menyelenggarakan sebuah kegiatan yang menarik perhatian bagi organisasi internasional. Dengan petisi Babakan Siliwangi tentang Penyelamatan Babakan Siliwangi, kementerian lingkungan mengusulkan kepada United Nations Environment Programme (UNEP) agar petisi tersebut dijadikan deklarasi lingkungan secara lebih formal bahkan diakui secara internasional. Akhirnya, kegiatan ini diformalkan dalam sebuah konferensi internasional «The United Nations Environment Programme (UNEP)» Tunza International Children \& Youth Conference On The Environment dari tanggal 27 September sampai 1 Oktober 2011, di Bandung. Konferensi tersebut akhirnya menghasilkan deklarasi bahwa Babakan Siliwangi menjadi hutan kota yang pertama di Indonesia, dan untuk itu menteri lingkungan hidup republik Indonesia berpendapat:

Sehubungan dengan deklaratsi Babakan Siliwangi yang menetapkan Babakan Siliwangi sebagai hutan kota, bagi kami, ini adalah suatu ide yang brilliant dari genereasi muda Indonesia yang merupakan kaum yang peduli terhadap lingkungan, bagi masa depan yang kota-kota di Indonesia yang lebih baik. Hal ini juga merupakan konfirmasi bahwa dengan forum yang berkelas dunia ini, kita dapat mengungkapkan ide-ide kita ke berbagai peserta konferensi. Tujuan dari kegiatan ini adalah untuk mengingatkan generasi muda Indonesia untuk mengingatkan generasi muda akan perannya terhadap pentingnya pembangunan yang berkelanjutan. (Gusti Muhammad Hatta, Menteri LIngkungan Hidup, wawancara yang dipublikasikan di PRLM, 21 Septembre 2011) 
Terkait dengan deklarasi tersebut, Ridwan KAMIL, sebagai inisiator deklarasi tersebut memberikan pendapatnya bahwa:

Deklarasi Babakan Siliwangi sebagai hutan kota pertama di Indonesia hanya merupakan awal dari gerakan masyarakat sipil di Indonesia tentang ruang publik. Langkah tersebut perlu dilanjutkan oleh masyarakat sipil untuk meningkatkan kualitas ruang tersebut sebagai ruang publik yang sebenar-benarnya. (Ridwan KAMIL Bandung Creative City Forum (BCCF), wawancara yang diterbitkan di KOMPAS.com, 21 September, 2011)

Melihat dari program-program Bandung Creative City Forum ini, kita dapat mengamati hal-hal sebagai berikut:

1. Di Indonesia, saat ini telah muncul generasi baru yang dapat memobilisasi diri dalam menjawab permasalahan ruang kota dengan menggunakan pendekatan yang berbeda dengan pemegang kebijakan atau pemerintah.

2. Kegiatan yang dilakukan komunitas kreatif tersebut sepintas mirip dengan model pengembalian fungsi ruang kota di negara-negara barat. Jika kita mengamati lebih lanjut festival budaya dan kuliner yang diselenggarakan mirip dengan kegiatan di negara-negara amerika dan eropa. Adapun sayembara dan workshop akupuntur kota merupakan ide yang strategis untuk memobilisasi dan memberikan kesadaran pada masyarakat mengenai pentingnya keberlanjutan dan kebutuhan akan ruang publik yang baik.

Berdasarkan fakta-fakta tersebut di atas, kita dapat melihat bahwa di Bandung telah berkembang suatu mode pengembalian fungsi ruang kota sebagaimana yang terjadi di luar negeri, yang dikembangkan oleh para generasi muda. Beberapa hal yang dapat ditarik kemudian adalah bahwa penyebaran tersebut terjadi melalui tiga jalur:

1. Penyebaran tersebut berasal dari inisiatif tokoh masyarakat penting di Bandung. Dalam kasus ini, Ridwan Kamil merupakan tokoh pendukung dan penasihat aktivitas Bandung Creative City Forum Beliau adalah arsitek dan direktur utama konsultan « Urbane ». Lulusan dari master Urban Desain dari Universitas California, Berkelay, Amerika Serikat ini memperoleh penghargaan baik nasional ataupun internasional.

2. Model ini juga berasal dari fakta bahwa Bandung merupakan kota mahasiswa, atau sering disebut sebagai kota "Think Tank". Adanya ratusan universitas di metropolitan Bandung menjadikan kota ini menjadi lahan subur berkembangnya ide-ide baru dari mahasiswamahasiswanya. Kemudian, kita juga dapat melihat bahwa dalam kegiatan perkuliahan, khususnya dibidang penataan kota dan arsitek, sering mengambil contoh pengalaman penataan ruang di negara barat atau bahkan sering dilakukan studi banding ke negara lain yang lebih maju penataan ruangnya, seperti Singapore atau Jepang.

3. Adapun jalan ketiga penyebaran model penataan ruang publik adalah melalui arus globalisasi. Kebebasan memperoleh informasi tanpa adanya batasan geografis menyebabkan penyebaran informasi atau pengalaman yang penataan ruang di luar negeri dapat dilakukan secara lebih cepat dan mudah.

\section{KESIMPULAN}

Setelah mengungkap persoalan di kawasan sekitar Sungai Cikapundung, kita dapat melihat Indonesia sebagai sebuah negara yang memiliki karakter perkotaan yang kompleks. Demokrasi yang berkembang sejak tahun 1998 benar-benar berpengaruh terhadap kehidupan politik, sosial, dan ekonomi di setiap level. Adanya kebijakan desentralisasi pada kota-kota di Indonesia menyebabkan perubahan dalam kehidupan kondisi politik, sosial, ekonomi, dan lingkungan. 
Kita dapat melihat bahwa pertumbuhan ekonomi merupakan isu yang sangat penting bagi pemerintah di semua level pemerintahan, baik nasional, provinsi, kota, dan juga kawasan. Hal ini juga berhubungan dengan usaha pemerintah untuk mengembangkan wilayah dengan tujuan mensejahterakan dan kenyamanan masyarakat. Namun demikian, demokrasi juga berpengaruh terhadap perubahan drastis kehidupan sosial kemasyarakatan, pada kebebasan berpendapat, melontarkan ide, gagasan atau bahkan penolakan terhadap suatu ide. Hal ini merupakan kekuatan yang tidak terelakan bagi masyarakat sipil Indonesia. Selain itu, kita juga dapat melihat kehadiran generasi muda yang lebih sensitif dan perhatian terhadap ruang kotanya. Mereka adalah generasi terdidik, yang memiliki akses informasi yang mudah terhadap metode penataan ruang dan pengalaman pengembalian fungsi ruang di negara-negara asing. Metode dan pengalaman ini dapat diterima generasi baru ini melalui tiga cara, yakni atas inisiatif tokoh masyarakat penting, pendidikan di kampus, dan jaringan informasi elektronik berkat globalisasi. Sebagai akibatnya, generasi baru ini mempergunakan cara dan pendekatan yang berbeda dari pemegang kebijakan publik (pemerintah). Mereka ini juga turut berperan dalam membuka pikiran masyarakat terhadap ide-ide baru dalam penataan ruang.

Terkait dengan situasi terkini mengenai Sungai Cikapundung, kita dapat mengamati bahwa sekarang ini stakeholder terkait sedang berada pada tahap mencari sebuah model pengembalian ruang sekitar sungai. Namun demikian, sampai sekarang ini, stakeholderstakeholder tersebut belum dapat menentukan model yang cocok dengan kebutuhan kolektif warga Bandung. Melihat beragamnya kepentingan yang muncul dalam pelaksanaan proyek, kita dapat menyimpulkan bahwa tidak ada kesinambungan keinginan dan gerakan antara pemerintah dan masyarakat sipil, atau dengan kata lain tidak ada sistem pemerintahan yang dapat mewadahi aspirasi stakeholder terkait. Untuk menemukan solusi terbaik dalam penataan ruang publik di bantaran Sungai Cikapundung ini, adalah sangat penting untuk mengembangkan kebijakan pengembalian fungsi sungai yang dapat menyeimbangkan kepentingan ekonomi, sosial, dan lingkungan.

\section{DAFTAR PUSTAKA}

Bappeda Propinsi Jawa Barat, 2011. "Presentasi Gubernur Jabar MCB”, Powerpoint. Bandung, 25 Mei 2011.

Buchoud, Nicolas. 2011. "Les photos de Bandung 9-15 Aout 2011".

Dinas Tata Ruang dan Cipta Karya Kota Bandung. 2010. "Konsultasi publik perumusan visi, misi, dan strategi pengembangan permukiman dan infrastruktur perkotaan Bandung”, Power point, Bandung, Java Barat.

Dinas Tata Ruang dan Cipta Karya Kota Bandung. 2010. "Rencana Pengembangan Kawasan Permukiman Prioritas" Power point Bandung, Java Barat.

Komunitas Bandung Creative City Forum. 2011. Babakan Siliwangi, Bandung Inisiatif, Bccf, Juara Sayembara Desain Babakan Siliwangi, Sayembara Desain Babakan Siliwangi, tersedia di http ://bandungcreativecityforum.wordpress.com /2011/08. Diakses pada tanggal 1 September 2011.

Miranda, Mónica. 2010. "L'evenement urbain festif : vers une "gestion de site exploratoire » sur l] Est,», 492 p, Dir. Alain Bourdin.

Pratomo, Banirohim, Akbar. 2010. Normalisasi Kawasan Sungai Cikapundung, Bandung, dokumen riset, jurusan Arsitektur, Institut Teknologi Bandung.

Rencana Tata Ruang Wilayah Kota Bandung 2010-2030, Pemerintah Kota Bandung, 2009. 